\title{
IMPLICAREA SOCIALĂ A BISERICII - PRIORITATE A MISIUNII INTERNE CONTEMPORANE
}

George Istodor *

\begin{abstract}
The social involvement of the Church is and will be a priority of the ecclesiastic internal mission an act born by God's love for all the people and from the love of the neighbor including of the enemies, as an order and an absolute evangelic advice. Although the absolute priority of the orthodox religious life resides in the liturgical dimension of religion, still the social assistance remains fundamental in efficient and concrete combating of poverty, of the immigration and of any other form that leads to the dehumanization of the human being. The Church social assistance does not have to have an objective the material religion of the human being, but, in the first place, the enrichment in God of the contemporary human being and must show all of us alive and dynamic in the Christ Church combining, in the religious life the contemplation with the action the prey with the self help. The Orthodox social assistance does not have to feed the passions of the human being and does not encourage, in any way, any form of begging.
\end{abstract}

Key words: social assistance, internal ecclesial mission, poverty, immigration, family, human person, the early church, Vasiliada, philanthropy

\section{Introducere}

Misiunea internă a Bisericii are ca parte integrată asistența socială pe care aceasta trebuie să o manifeste cu privire la omul

\footnotetext{
* PhD, Rev Professor, “Ovidius” University, Faculty of Orthodox Theology, Constanța, Romania.
} 
contemporan şi la societatea actuală. Implicarea în social a Bisericii care este deopotrivă deziderat, necesitate şi prioritate. Este deziderat pentru că presupune efortul nostru de a răspunde lui Dumnezeu, chemării Lui, de a ajuta pe cei în nevoi şi suferințe, slujirea acestora înseamnă - în registrul chenotic hristic - slujirea lui Dumnezeu însuşi. Este necesitate pentru că vine în ajutorul semenilor în mod concret, accentuează dinamismul vieții misionar-religioase şi ne arată vii în relaţia de ascultare şi comuniune cu Sfânta Treime, dar şi în relația plină de iubire şi milă faţă de aproapele suferind. Este, de asemenea, prioritate pentru că ordonează şi ierarhizează în mod firesc propria noastră acţiune misionară pe planul iconomic, accentuând aspectul instituțional al Bisericii în lucrarea sa în lume.

Biserica, după modelul absolut al Mântuitorului, are în ființa sa teandrică două aspecte care se îmbină în mod armonios: 1) aspectul duhovnicesc care ține de relația cu Dumnezeu în Biserică dar şi în sufletele credincioşilor care este fundamentală; 2) aspectul instituțional al Bisericii care îi permite acesteia să inter-relaționeze cu celelalte instituții fundamentale ale statului iar prin această cooperare să se ajungă la ajutorarea concretă a celor în nevoi şi suferințe.

Primului aspect îi corespunde implicarea socială a Bisericii ce izvorăşte din iubirea aproapelui, iar aceasta se întemeiază pe iubirea omului faţă de Dumnezeu şi, mai ales, pe iubirea lui Dumnezeu faţă de om. Iubirea creştină nu se epuizează în iubirea lui de Dumnezeu. ${ }^{1}$ Ea cuprinde, ca parte constitutivă şi iubirea

${ }^{1}$ Ființa divină nu poate fi înțeleasă şi contemplată, în viața sa interioară treimică, decât ca „plenitudinea iubirii” existente în persoane şi între persoane. Această iubire nu este ceva static, limitat, în mod exclusiv, la raportul dintre Persoanele Treimice, ci se revarsă în afară, în creație, Treimea fiind izvorul iubirii, care se revarsă şi se manifestă plenar asupra omului. „Iubiților, să ne iubim unii pe alții, pentru că dragostea este de la Dumnezeu şi oricine iubeşte este născut din Dumnezeu şi cunoaşte pe Dumnezeu, Care ...rămâne întru noi şi dragostea lui în noi este desăvârşită" (I Ioan 4, 7, 12). De aceea , creştinismul înfățişează pe Dumnezeu ca pe „un Dumnezeu familiar care vrea pe fiii săi strânşi în jurul Lui, un Dumnezeu iubitor de oameni, cum este preamărit şi invocat în atâtea din ecfonisele rugăciunilor ortodoxe: $<<c a ̆$ bun şi iubitor de 
aproapelui „, Iar a doua poruncă - zice Mântuitorul - este să iubeşti pe aproapele tău ca pe tine însuți” (Matei 22, 38). Această poruncă este mai veche decât creştinismul. Dar Iisus Hristos este Acela care o investeşte cu forța menită să o ducă la înfăptuirea unor revoluționare răsturnări morale. Adevărata rădăcină a acestei iubiri este aceeaşi din care răsare şi iubirea către Dumnezeu, este iubirea lui Dumnezeu către om. Iubirea creştină către aproapele este fiinţial legată de iubirea către Dumnezeu.

Sub pretextul iubirii lui Dumnezeu, omul a fost urât şi disprețuit, torturat şi ucis. Iată de ce evanghelistul Ioan numeşte mincinos pe cel care zice că iubeşte pe Dumnezeu, iar pe fratele său îl urăşte. Pentru că cel ce nu iubeşte pe fratele său, pe care 1-a văzut, pe Dumnezeu, pe care nu L-a văzut, nu poate să-L iubească, căci porunca lui Hristos este: cine iubeşte pe Dumnezeu să iubească şi pe fratele său (I Ioan 4, 20-21).

Neîncadrată în iubirea lui Dumnezeu, iubirea de semeni poate degenera în mijlocul de exploatare a semenului în folos personal; sau poate să substituie iubirea creştină cu iubirea umanitară capitalistă în care omul ajunge doar o unealtă de producție economică şi poate să conducă la confundarea iubirii creştine cu sentimentul de milă. De aceea, asistența socială făcută în lipsa de iubire a semenului tău este seacă şi nu duce niciodată la bun sfârşit ${ }^{2}$.

Celui de-al doilea aspect îi corespunde asistența socială a Bisericii ca activitatea eficientă şi mântuitoare a celor integraţi în ea, într-un dialog constructiv cu toate instituțiile statului ce-şi propun slujirea şi ajutorarea celor în nevoi. Creştinismul înainte de a fi o filozofie şi de a avea, un concept despre viață, reprezintă anumite principii de conducere socială, care trebuiesc să fie realizate. Am putea spune că creştinismul în general - noi vorbim şi de Biserica Ortodoxă în speță - are anumite norme, pe care credincioşii trebuie să le urmeze în alcătuirea socială.

oameni Dumnezeu eşti...>>”. (Pr. Prof. Ene Branişte, Idei, principii şi preocupări sociale în cultul Bisericii Ortodoxe, în Studii Teologice, an IV, nr. 7-8, 1952, p. 436.

${ }^{2}$ Florica Mănoiu, Viorica Epureanu, Asistența socială în România, în "S.T.” nr. 5-6, 1991, p. 5. 
Aici intră diferite probleme, care privesc Biserica în faţa societății, cum ar fi de pildă Biserica şi problemele sociale, Biserica şi problema familiei, Biserica şi problemele economice, atitudinea, pe care o are Biserica față de proprietate, de capital şi de muncă, față de educaţia tineretului, Biserica în relaţiile internaţionale, etc. Este necesar să urmărim tot ce s-a făcut sau se face în această privință, spre a înţelege mai bine rostul aplicării principiilor creştine în viaţa contemporană ${ }^{3}$.

Oricât de perfecționate ar fi tehnicile asistenței sociale, dacă nu cuprind în ele sâmburele care te propulsează spre utilitate şi eficiență - mila creştină, iubirea aproapelui, înţelegerea, toleranţa zadarnice sunt încercările asistentului social de a le pune în aplicare, pentru că omul aflat la suferință vine spre el ca la un duhovnic, descoperindu-şi sufletul şi cerându-i ajutorul pentru a putea ieşi din situația critică în care se află în domeniul asistenței sociale, trebuie să existe mereu o strânsă colaborare între specialist - asistentul social şi Biserică spre a reuşi, ca terapia socială sa aibă cele mai bune efecte. Sunt mulți preoți care la Sfânta Taină a Mărturisirii sugerează credincioşilor drept canon ajutorul dat unei familii în suferinţă, acțiuni de binefacere, de milostenie, grijă pentru un copil orfan sau părăsit. ${ }^{4}$

Aşadar, observăm de la început că toată activitatea socială a Bisericii se integrează misiunii interne a acesteia, de aceea, înainte să vorbim despre asistența socială a Bisericii, trebuie să vorbim despre misiunea internă a Bisericii lui Hristos.

\section{Misiunea internă a Bisericii}

Înainte să teoretizăm cu privire la misiunea internă a Bisericii este necesar să accentuăm fundamentarea doctrinară a misiunii ortodoxe. Astfel, vorbim despre temeiurile doctrinare ale misiunii, cel divin, cel eclesiologic, cel antropologic şi, în fine, cel legat de

\footnotetext{
${ }^{3}$ Vasile Ispir, Curs de îndrumări misionare, Editura Buna Vestire, Bucureşti, 1929, p. 399

${ }^{4}$ Florica Mănoiu, Viorica Epureanu, art.cit., p. 7.
} 
importanța covârşitoare a Cincizecimii cu privire la misiunea Bisericii, atât internă, cât şi externă. Temeiul divin are în esență legătură cu trimiterea Sfântului Duh de către Tatăl în lume, dar şi trimiterea Fiului în lume de către Tatăl şi Duhul Sfânt la plinirea vremii (Galateni IV, 4). Acest temei descoperă taina Sfintei Treimi în raport cu omul şi creația în baza apropierii. Toată această lucrare a Sfintei Treimi este dovada iubirii cu care a fost binecuvântată creația, este hotărârea veşnică a lui Dumnezeu de a mântui şi sfinți toate cele existente, aceste lucrări ale Persoanelor Treimice dovedind acte temporale prin voința lui Dumnezeu 5 .

Înțelegând importanța temeiurilor doctrinare ale misiunii, să vedem în ce constă misiunea internă a Bisericii. Dacă prin misiunea externă a Bisericii se urmăreşte răspândirea creştinismului la cei necredincioşi, prin misiunea internă cu mijloacele ei specifice se urmăreşte întărirea Bisericii de acasă prin lupta împotriva relelor societății, prin mişcarea socială în creştinism, prin formarea şi transfigurarea creştinilor ortodocşi, ca bază pentru înfăptuirea operei misionare externe a Bisericii. Astfel, misiunea internă este activitatea care întăreşte misiunea externă, iar cea externă este reflexul vieții religioase ce nu se poate manifesta decât pe fundamentul activității misionare interne. Această activitate este în legătură cu evanghelizarea poporului, cu misionarismul în popor, cu tâlcuirea în popor a sfintelor evanghelii, pentru ca poporul lui Dumnezeu să devină luminat în spiritul Evangheliei lui Hristos ${ }^{6}$. Textul scripturistic ce fundamentează misiunea internă este cel de la Luca XXIV, 47: „şi să se propovăduiască întru numele Lui pocăința şi iertarea păcatelor în toate neamurile începând de la Ierusalim" adică de acasă şi apoi să răspândim Evanghelia la toate neamurile (misiunea externă). Avem exemplul Mântuitorului, Care şi-a început activitatea din Palestina, în sânul poporului iudei, ceea ce învederează că, odată cu activitatea în afară de biserică, misionarul

${ }^{5}$ Gheorghe Istodor, Introducere în misiologia ortodoxă, Editura Do-Minor, Bucureşti, 2009, p. 20.

6 Vasile Ispir, Curs de indrumări misionare, Editura Buna Vestire, Bucureşti, 1929, p. 153. 
este obligat să se ocupe de situația poporului din sânul căruia pleacă după exemplul Mântuitorului: „Nu sunt trimis decât către oile cele pierdute ale casei lui Israel: (Matei XV, 24) ${ }^{7}$.

Lacunele activitătii misionare interne ale Bisericii se văd mai ales în dezvoltarea sectarismului în biserică, adică acei oameni care caută să interpreteze Sfânta Scriptură într-un anumit fel încât ajung să nu se mai supună hotărârilor tradiționale bisericeşti şi nu vor să recunoască autoritatea bisericească. Alături de această prioritate a misiunii interne, predicarea evangheliei trebuie să aibă în vedere şi mizeria socială ca imoralitate dar şi fenomenul imigrației etc. Deoarece prioritatea este implementarea misionară a unei adevărate „cruciade a sufletelor”, adică a cuceririi şi salvării sufletelor creştinilor pentru Hristos.

Trebuie, de asemenea, să nu confundăm misiunea internă cu pastorația, activitatea misionară aduce la biserică, pe când cea pastorală menține în biserică, de aceea activitatea misionară poate fi îndeplinită şi de credincioşi laici, pe când activitatea pastorală este destinată chemării exclusive a preotului. Deşi merg împreună, totuşi misiunea internă pregăteşte pentru oficiul superior al păstorului ${ }^{9}$.

Cuvântul „misiune internă” este un cuvânt nou în arealul teologiei creştine, provenit din lumea evanghelic-protestantă, de la Johann Hinrich Wichern (1808-1881) care a scris o lucrare asupra misiunii interne a Bisericii Evanghelice Germane: „Die innere Mission der deutschen evangelischen Kirche. Eine Denkschrift an die deutsche Nation", apărută în anul 1849 la Hamburg, fiind apoi generalizată şi în cadrul teologiei catolice sau ortodoxe. Dincolo de tratat, Wichern a înființat o casă de patronaj „Das rauhe Hans” în Hamburg în 1833, cu scopul de a îngriji pe cei sărmani, părăsiți sau decăzuţi înlăuntrul comunitătii evanghelice, din cauza războaielor napoleoniene a liberalismului economic, a filosofiei utilitariste a lui Bentharn, dar şi influenței tot mai mari a curentelor materialiste, care au transformat din temelii societatea germană, transformând-o într-o

\footnotetext{
${ }^{7}$ Ibidem, pp. 154-157.

${ }^{8}$ Ibidem.

${ }^{9}$ Ibidem, pp. 158 .
} 
societate în care concurența animalică devine prioritară, din care trebuia să iasă învingător cel mai bine echipat din punct de vedere trupeşte, din cauză că viaţa omului este comparată în filosofia interbelică (ca şi acum) cu viața animalului ${ }^{10}$.

Această activitate creştină, centrată pe filantropie a fost numită misiune internă şi are la bază două motive: primul este loialitatea faţă de Mântuitorul Iisus Hristos, având certitudinea că învățătura Lui este cea adevărată; al doilea motiv al misiunii interne este legat de responsabilitatea socială ce o avem față de semenii noştri, această concepție socială face din creştinism o unitate în cadrul istoriei religiilor.

Misiunea internă se bazează în implicarea social - pe iubirea faţă de aproapele, având ca deziderat atât mântuirea personală a omului, cât şi pe cea comunitară, ca o consecinţă a credinței şi doctrinei Bisericii. Între mijloacele şi metodele misiunii interne, menţionăm pe cele de ordin social, moral şi cultural. Din perspectiva Prea Sfințitului Bartolomeu Stănescu, se disting între căile misiunii mijloace culturale, de moralitate şi de asistență materială.

\section{Asistența socială a Bisericii în perioada primară şi în zilele noastre}

Când evaluăm implicarea socială a Bisericii, trebuie să ne raportăm la perioada primară a acesteia, chiar dacă unii sceptici şi critici ar putea aduce obiecții cu privire la diferențele sociale şi instituţionale între perioada antică a apariției istorice a Bisericii şi perioada post-modernă a acesteia în contemporaneitate. Chiar dacă sunt şi diferențe clare între cele două epoci amintite, totuşi există şi foarte multe similitudini care țin în special de sărăcie, de instabilitate socială şi de un anumit tip de dependență în care trăieşte omul contemporan, foarte apropiat de structurile sclavagiste ale societății păgâne romane. Mai mult, faptul că în perioada cruntă a persecuțiilor romane s-a putut face asistență socială, care a luat mare amploare după Edictul de toleranță din 313 d.Hr. al Sfântului împărat

${ }^{10}$ Ibidem, p. 159. 
Constantin cel Mare, cu atât mai mult se poate face asistență socială în zilele noastre, mai ales după prăbuşirea sistemului dictatorial ateu comunist.

Când vorbim despre asistența socială în Biserică, trebuie să facem referire la personalitatea centrală a acesteia: Sfântul Vasile cel Mare. Activitatea depusă de el pe tărâmul asistenței sociale, numită „vasiliada" ${ }^{\prime 11}$ reprezintă începutul organizat al asistenței sociale în Biserică. Dar şi ceilalți Sfinți Părinți au avut preocupări legate de asistența socială. Dacă în Sparta antică, copiii cu deficiențe vizibile la naştere erau selectaţi şi aruncaţi în prăpastie de pe muntele Taiget $^{12}$, creştinismul atrage pe săraci în centrul său de activitate. ${ }^{13}$

Sfântul Vasile cel Mare, referindu-se la cei aflați în suferință a scris omilii la textul ,voi dărâma ființele mele şi mai mari le voi zidi”. La baza activității filantropice au stat două idei: egalitatea dintre oameni şi bolnavul ca victimă a sărăciei. Sfântul Vasile se

11 Semnificativă în acest sens este Scrisoarea 94 adresată guvernatorului provinciei Capadocia. Din răspunsul său, care pentru frumusețea sa complexă merită a fi redat, rezultă deodată şi amploarea Vasiliadei, precum şi grija deosebită a Bisericii față de cei nevoiaşi, şi personalitatea deosebită a marelui Ierarh. În scrisoare, între altele, îl întreabă pe guvernator: "Ce greşim noi față de Stat, sau ce fel de interes obştesc, mic sau mare, se nesocoteşte dacă noi ne administrăm singuri Bisericile? Afară, poate, de cazul că ar putea spune cineva că aducem prejudicii statului atunci când ridicăm Dumnezeului nostru câte un lăcaş de rugăciune mai spațios, cu câteva locuințe în jurul lui, din care una mai arătoasă rezervată Episcopului, iar celelalte mai modeste pentru slujbaşii bisericeşti din subordine...pe cine neîndreptăţim, noi oare când construim hoteluri şi aziluri pentru străinii care vin pe la noi în trecere şi care au vreo suferinţă de tămăduit? Sau, în sfârşit, când facem aşezăminte trebuitoare uşurărilor cu infirmieri, doctori, animale pentru povoară, cu personal auxiliar? Căci a fost nevoie, într-adevăr, să mai prevedem aici şi multe feluri de meserii şi ateliere necesare vieții precum şi tot ceea ce mintea omenească a putut născoci pentru menținerea unei vieți onorabile. În fine şi alte spații pentru diferite munci manuale; lucruri care în totalitatea lor sunt o adevărată podoabă pentru oraşul nostru.( Ion Vicovan, Dați-le voi să mănânce!. Filantropia creştină: istorie şi spiritualitate, Ed. Trinitas, Iaşi, 2001, p. 82)

12 Ilie Stănică, Mariana Popa, Elemente de psiho-pedegogia deficiențelor de auz, Bucureşti, 1994, p. 154.

${ }^{13}$ Nicu Cotlarciuc, Ocrotirea socială şi Biserica, Cernăuți, 1921, p. 2. 
referă la sărăcie în felul următor: „Dacă toți şi-ar împărți deopotrivă averile şi le-ar da săracilor, atunci fiecare ar putea primi puțin pentru îndestularea nevoilor lor. Atunci cel care iubeşte pe aproapele său ca pe sine însuşi n-ar avea mai mult decât semenul său, ori tu ai mai multe bogăţiii? De unde această inegalitate în averi? Negreşit, de acolo că preferi propria-ți desfătare în locul ajutorării celor mulți. Prin urmare, cu cât îți înmulțeşti avuția, cu atât îți împuținezi dragostea de aproapele"14. Cea mai importantă faptă a Sfântului Vasile cel Mare în domeniul carității a fost înființarea Aşezământului de la Cezareea.

Acțiunea Sfântului Vasile nu s-a limitat numai la a asigura hrana zilnică, ci avea în atenție şi îngrijirea leproşilor, asigurarea unui adăpost bătrânilor nevoiaşi (aziluri), case de oaspeți, şcoli în care copiii învățau carte şi meserii. Pentru întreținerea Aşezământului, înşişi infirmierii lucrau în ateliere aducând cele necesare funcționării. Faima câştigată în timp de acest aşezământ a atras vizitatori cu stare, care contribuiau cu diferite sume şi obiecte. Pilda Sfântului Vasile a constituit îndemn şi pentru alți creștini. ${ }^{15}$ Astfel Sfântul Efrem de Edessa, a clădit în 375 d.Hr. un spital cu capacitate de 300 de paturi pentru bolnavii de ciumă. După spusele

${ }^{14}$ Ioan Gh. Coman, Rolul social al milei creştine la părinții capadocieni, Bucureşti, 1945, p. 5.

${ }^{15}$ Pentru Sfântul Ioan Gură de Aur comunitatea model, spre care a tins în activitatea sa de păstor fie la Antiohia, fie la Constantinopol, a rămas cea din Biserica primară, descrisă de cartea Faptele Apostolilor. De aceea, el dă mereu ca exemplu pe cei dintâi creştini, care au depus la picioarele apostolilor tot ce aveau, urmând să primească fiecare după nevoie. El spune că dacă bogații şi-ar vinde bunurile lor, nu ei ar deveni săraci, ci săracii ar deveni bogați. Pe la anul 390, pe vremea când era preot şi predicator în Antiohia, arată cum se desfăşura activitatea filantropică a Bisericii în oraşul amintit. El afirmă că multe văduve şi fecioare erau întreținute zilnic. În acest scop, Biserica folosea, în afară de veniturile ei, donaţii din partea creştinilor modeşti şi nicidecum din partea vreunui bogat. Lista celor sprijiniţi de Biserică cuprindea un număr de 3000 de nume. În afară de aceştia, Biserica oferea ajutor celor închişi, bolnavilor, celor săraci, străinilor, infirmilor şi tuturor celor care aşteptau alimente şi haine. Sfântul Ioan nu mai pune la socoteală pe cerşetorii ocazionali, care, de asemenea, se ridicau la un număr destul de mare (Ion Vicovan, op.cit., p. 84). 
Fericitului Ieronim, văduva Fabiola şi Sfânta Paula şi-au clădit şi ele câte un spital. La fel Sfântul Ioan cel Milostiv a ridicat în anul 610 d.Hr. mai multe spitale în Alexandria. Sfârşitul „Vasiliadei” a fost declanşat din cauza mai multor cutremure ale vulcanului Ange. Ce a reuşit să rămână în picioare a fost devastat mai târziu în 1024 de cuceririle islamice. ${ }^{16}$

În veacul apostolic, asistența socială se realiza sub trei forme:

1 - ofranda, se aducea pâine, vin şi apă.

2 - colecta - în anul 44 d. Hr, Biserica din Antiohia face întro vreme de foamete, o bogată colectă pentru Biserica din India şi trimite aceste ajutoare prin Sfinții Apostoli (F.A. 11, 27-30).

3 - agapa - dacă ofranda şi colecta existau şi la iudei, agapa este specifică creştinilor deoarece temelia acesteia este fãcută de Însuşi Iisus Hristos, care a instituit Sfânta Euharistie la o masă comună; multe locuri din Sfânta Scriptură arată, printre creştini această practică: F A 2, 46; 20, 6-11; I Cor 11, 33.

Slujirea Noului Testament nu se poate descrie folosind termenii de autoritate sau de dominație, pentru că autoritatea apostolică a fost înțeleasă ca slujire „Deşi sunt liber față de toți, mam făcut rob al tuturor, ca să dobândesc pe cei mai mulți” (I Cor. 9, 19) spune Sfântul Apostol Pavel, arătând prin aceasta că libertatea creştină implică responsabilitate pentru adulți. ${ }^{17}$ Astfel suntem îndreptățiţi să afirmăm că adevărata diaconie, slujire şi asistență socială este insuflată de Mântuitorul Iisus Hristos şi Biserica Sa ca rezultat al activității şi învățăturii Sale pe pământ.

Cei care se întreabă astăzi „Biserica de ce nu se implică?” demonstrează că nu-şi cunosc istoria propriei Biserici şi chiar a propriei existențe. Cei care critică neîmplinirea Bisericii în anumite activități, cei care sunt nemulțumiţi de activitatea ei din punct de vedere social, trebuie să fie nemulţumiţi de ei înşişi, care, ca adevăraţi creştini, nu au făcut nimic pentru Biserică şi pentru

${ }^{16}$ Sf. Vasile cel Mare, Cuvânt în Duminica a XII-a după Rusalii, trad. de Dumitru Fecioru, Mitropolia Olteniei, 1968, nr 9-10, p. 785.

17 Antonie Plamădeală, Biserica slujitoare în Sfântul Scriptură, în Sfântul Tradiție şi în teologia contemporană, teză de doctorat, în ST, nr 5-8/1972, pp. 280-281. 
aproapele. ${ }^{18}$ Într-un sens larg acceptat, asistența socială cuprinde „un ansamblu de instituții, programe, măsuri şi activități personalizate de protejare a unor persoane, grupuri, comunități cu probleme sociale, aflate temporar în dificultate, în criză şi deci vulnerabile. ${ }^{19}$

Sfântul Sinod al Bisericii Ortodoxe Române a aprobat prin hotărârea nr. 3336 din mai 1997 „Regulamentul de organizare şi funcționare a sistemului de asistență socială a BOR", prin care activitatea social-caritativă se structurează într-un cadru organizat şi coerent, fiind realizat de asistenți sociali, teologi profesionişti pregătiţi în cadrul secțiilor de asistență socială din Facultățile de Teologie din țară şi de asistenţi medicali pregătiţi în Şcoli Postliceale Teologico-sanitare din cadrul Patriarhiei. În cadrul Sectorului „Biserica şi Societatea”, la nivelul Patriarhiei Române, funcționează Biroul de Asistență Socială al Patriarhiei Române. De aici se coordonează şi se îndrumă activitatea socială în cadrul Patriarhiei Române, potrivit îndrumărilor Sfântului Sinod şi se analizează problemele legate de activitatea socială şi filantropică a Bisericii, prezentând Sfântului Sinod propuneri în vederea îmbunătățirii acesteia.

La nivelul Administrației Patriarhale, a luat ființă în anul 1993, Sectorul pentru Opera de Caritate „Diaconia” care îşi propune sprijinirea diferitelor instituții bisericeşti pentru inițierea unor activități cu caracter social precum şi înființarea unor instituții de asistenţă socială sau gestionarea unor programe de asistență socială şi religioasă.

Biserica are în vedere rezolvarea tuturor problemelor cu care se confruntă de la prozelitism religios la prostituție, de la satanism şi ocultism la avort şi clonare. Lumea este creația întreagă pe care Dumnezeu a iubit-o atât de mult, încât pentru slujirea ei spre mântuire, Dumnezeu a trimis pe Fiul Său (In 3, 16-17), care la rândul Său trimite pe Apostoli şi prin ei Hristos trimite Biserica însăşi.

${ }^{18}$ Daniel Necula, Biserica de ce nu se implică?, în rev Glasul Adevărului, edit Ep. Buzăului, an XI, nr. 110-112, ian.-mart. 2000, p. 122.

${ }^{19}$ Elena Zamfir, Dicționar de Sociologie - Asistență socială, Editura Babel, Bucureşti, 1998, p. 46. 
Slujirea pe care Biserica este datoare lumii după exemplul capului ei, Hristos, care n-a venit să I se slujească, ci ca El Însuşi să slujească şi să-Şi dea viaţa răscumpărare pentru mulţi $(\mathrm{Mc} 10,45) .{ }^{20}$

$\mathrm{Cu}$ privire la sărăcie, părintele Arsenie Boca ne arată că percepția pe care o avem față de una sau alta dintre stările materiale ne poate schimba conduita de viață. Astfel: ,nu sărăcia te mântuieşte, nici bogăţia nu te osândeşte; precum nici bogăția nu te mântuieşte, nici sărăcia nu te osândeşte, ci cum ai sufletul tău şi față de bogăție şi față de sărăcie. Eşti sărac şi zorit cu gândul după avere, iată că nu te mântuieşte sărăcia ta. Eşti bogat, dar desfăcut cu inima de bogăţia ta, iată că nu te primejduieşte bogăția ta. Cum stai cu sufletul şi față de una şi față de alta, de la asta atârnă mântuirea sau osânda ta" ${ }^{21}$.

Sărăcia este imposibilitatea unei persoane de a-şi satisface necesitățile de azi şi probabilitatea scăzută de a le satisface în viitor. Deci, sărăcia afectează negativ durabilitatea vieții unei persoane. Pe de altă parte, săracii sunt acele persoane care au un grad de confort mult mai scăzut şi, respectiv, calitatea vieții lor este mult inferioară comparativ cu alte categorii de populație. Sărăcia presupune confort scăzut în viața cotidiană a unei persoane, cauzat de lipsa (ineficiența) unor resurse, bunuri sau posibilități.

${ }^{20}$ Suportul acestei forme de filantropie este slujirea Domnului nostru Iisus Hristos, în toată complexitatea şi autenticitatea Sa. Fiul lui Dumnezeu "nu a venit să I se slujească, ci ca El să slujească şi să-Şi dea viaţa răscumpărare pentru mulți" (Marcu 10, 45). Hristos uneşe "măreția Fiului cu smerenia robului şi fundamentează adevăratul tip de slujire", slujirea jertfelnică. Unicul scop al slujirii lui Hristos a fost, deci, mântuirea omului, expresia dragostei Lui față de acesta. Fiid trimis de Dumnezeu Tatăl ca să slujească omului, înseamnă că, aşa cum spune Anthony T. Hanson, "într-un fel Dumnezeu Însuşi este Dumnezeu - Slujitor". Dimensiunea slujirii lui Hristos este dată de actul întrupării Sale, care prin semnificația adânc umană, ne învață că iubirea creştină a omului lui poate fi mărginită la ceea ce se numeşte adesea latura spirituală a vieții, nesocotind viața lui zilnică, ci trebuie să cuprindă în acțiunea lui pe omul întreg, în situația lui obiectivă în care se găseşte. (Mihai Vizitiu, Filantropia divină şi filantropia Bisericii după Noul Testament, Editura Trinitas, Iaşi, 2002, pp. 114-115).

${ }^{21}$ Arsenie Boca, Cuvinte vii, Editura Charisma Advertising, 2006, p. 10. 
Alături de sărăcie, o provocare deosebită la adresa misiunii eclesiale, ce are legătură cu asistența socială îl reprezintă fenomenul migrației. Tipurile de migrație/imigrație cu care se confruntă autoritățile române sunt similare celor întâlnite în toate celelalte State Membre ale Uniunii Europene (UE) şi care sunt reglementate prin mecanisme concertate şi agreate la nivel comunitar: imigrație permanentă legală (în special pentru reîntregirea familiei, căsătorie cu un cetățean român, repatriere); imigrație temporară legală (în această categorie se încadrează studenții, lucrătorii - aşa numita „migrație de înlocuire” , refugiații şi azilanții); migrație ilegală de tranzit; migrație circulatorie cu ajutorul rețelelor migratorii (legală sau ilegală). Gestionarea benefică a imigrației este deci echivalentă cu gestionarea eficientă şi eficace a resurselor publice alocate pentru crearea şi aplicarea legislației specific domeniului şi a instituțiilor implicate, precum şi pentru preîntâmpinarea unor riscuri şi vulnerabilităţi sistemice sau sectoriale generate de imigrația ilegală, contrabanda de migranţi, traficul de persoane. În acelaşi timp, ea reprezintă şi un model funcțional şi instituțional de adecvare la obiect, un cadru normative în raport cu dimensiunea de „normalitate” configurată de legislația europeană specifică şi premisele aderării la spațiul Schengen.

Migrația legală - care ar trebui să fie reglementată prin norme clare, transparente şi echitabile; în acelaşi timp se va ține cont de faptul că fiecare stat membru trebuie să păstreze controlul asupra numărului de lucrători migranți pe care îi poate integra pe piața forței de muncă, acordând atenția cuvenită preferinței comunitare; în toate statele membre, definirea noțiunii de „integrare” are o componentă ce ține de „asimilare” şi o alta care este tributară „multiculturalismului”, dar ponderea care este acordată uneia sau alteia dintre cele două domenii este extrem de diferită. Există experiențe diferite, există o istorie diferită la expunerea societăților europene, la fenomenele migratorii moderne şi contemporane, după cum există şi modalități diferite de a integra potențialul beneficiilor imigrației în politicile de dezvoltare particulară proprie fiecărui stat comunitar. În vreme ce unele țări sunt în etapa gestionării eficiente a controlului accesului pe teritoriul național, altele operaționalizează 
concepte specific ,asimilării” sau încurajează experiența „multiculturalismului”.

\section{Concluzii}

Am observat cât este de importantă asistența socială a Bisericii ce presupune în mod direct o responsabilitate socială a fiecărui creştin ortodox. Trebuie să precizăm că implicarea socială ca manifestare concretă a ethosului misionar ortodox în plan intern, este şi rămâne o prioritate doar în plan social, dat fiind faptul că în ansamblul vieții religioase ortodoxe cu scop soteriologic prioritatea absolută se regăseşte deplin în aspectul liturgic al vieții de comuniune cu Dumnezeu, prin Biserica Sa. Această precizare este fundamentală, deoarece confuzia, sau, mai grav, inversarea acestor priorități transformă ființial Biserica într-o instituție cvasi-lumească, dar cu aparența transcendenței şi a structurii sale hristice, structură ce ni-L descoperă ca prezență reală şi continuă pe Hristos Cel înviat, Dumnezeu adevărat şi Om adevărat. Inversarea valorică amintită ar face - cum constatăm la multitudinea denominațiunilor ce pretind a fi creştine - ca Biserica Mântuitorului să semene mai mult cu lumea decât cu El, Capul Său.

De asemenea, cele două provocări majore la care trebuie să răspundă implicarea socială a noastră sunt sărăcia şi imigrația. Prima este universală în temporalitatea istorică a omului, chiar dacă formele sale de manifestare diferă de la o perioadă istorică la alta. În schimb, imigrația este un fenomen nou, cu substrat social evident, cauzele acestuia fiind aproape în totalitate economico-sociale. Cele două provocări sunt grave şi periculoase în sine, dar mai ales cu privire la consecințele acestora. Astfel, sărăcia socială în evaluare misionară este expresia sărăciei duhovniceşti, a lipsei vieții religioase autentice a omului contemporan, a predispoziției omului autonom, desacralizat şi chiar decreştinat de azi de a-L exclude pe Dumnezeu din viața lui. În plus, gravitatea sărăciei sociale constă, dincolo de greutăţile cotidiene majore, în implicațiile morale ce riscă să-l dezumanizeze pe cel sărac. Sărăcia nu este în sine nici virtute, nici păcat, poate deveni virtute doar dacă remediul ei se întemeiază în primul rând pe 
îmbogățirea în Dumnezeu, cea materială după exemplul lui Iov adăugându-se, dar poate deveni păcat dacă invidia şi răutatea celui sărac devin o a doua „natură” a acestuia. $\mathrm{Nu}$ trebuie uitat nici faptul că sărăcia fără duhovnic nu se poate gestiona şi conduce la promiscuitate accentuată, la compromis şi la expunerea vulnerabilă față de tehnicile de manipulare a celor ce au resursele materiale în cadrul societății de azi. Imigrația - pe de altă parte - are consecințe grave la adresa familiei în ansamblu şi cu privire la educația şi creşterea duhovnicească şi trupească a copilului în societatea românească contemporană.

$\mathrm{Nu}$ în ultimul rând, implicarea socială a Bisericii trebuie să fie bazată pe marea virtute creştină a discernământului duhovnicesc, pe înțelegerea exactă a diferențelor psihologice şi sociale dintre dorințe şi nevoi şi mai ales pe descurajarea patimilor şi a modului de viață dezumanizat. Mai bine spus, orice formă de asistență socială nu trebuie în nicio situație să „hrănească” patimile sau lenea omului comod şi indiferent religios de astăzi sau, mai grav, să încurajeze cerşetoria ca pseudo-asistență socială. În concluzie, întreaga asistență socială ortodoxă trebuie să izvorască din iubirea lui Dumnezeu şi a noastră faţă de om şi să reflecte ambivalența atitudinii noastre sociale autentice: să fim plin de milă şi dragoste față de păcătos şi fără milă față de păcatele acestuia. 